\title{
Consumption dreams: how night dreams reveal the colonization of subjectivity by the imaginary of consumerism
}

\author{
Sueños de consumo: cómo los sueños revelan la \\ colonización de la subjetividad por el imaginario de consumo
}

Marlon Xavier

Universitat Autònoma de Barcelona, marlonx73@gmail.com

\begin{abstract}
Keywords

Consumption

Social Imaginary

Dream

Subjectivity

In this article I offer an overview of my doctoral dissertation, which studied the social imaginary of consumerism, and the psychological subjectivity it produces, through the dream - as both a leitmotif or thematic lens, and the empirical object of research. For such I employed an interdisciplinary exploratory outlook, whose theoretical framework first discusses the symbolic imaginaries (G. Durand) and their relations with the unconscious psyche, dream, imagination, and subjectivity (C. G. Jung), and then explores their relationships with consumption (Baudrillard, Bauman) and its semiotic imaginaries and ideology, focusing on the concepts of consumption dreams and dream-worlds of consumption. The main research aim was to explore how night dreams represent the colonization of subjectivity by the imaginary of consumerism. The method consisted in a multiple-case study in which each night dream was taken as a case and interpreted through Jungian hermeneutics. Findings stress that night dreams can offer a deep sociocultural critique; in them the imaginary of consumption appeared as a totalizing mass ideology engendering colonization of both symbolic imaginaries and the subject and her unconscious psyche. Conclusions emphasize such colonization as an anthropological mutation the progressive commodification and dehumanization of the subject.

\section{Resumen}

\section{Palabras clave}

Consumo

Imaginario social

Subjetividad

Sueño

En este articulo describo a grandes rasgos mi tesis doctoral, que investigó el imaginario social del consumismo, y el sujeto psicológico que el mismo produce, a través del sueño - como leitmotif o lente temática y como objeto de investigación empírica. Para eso desarrolla un abordaje exploratorio interdisciplinar, cuyo marco teórico discute primero los imaginarios simbólicos (G. Durand) y sus relaciones con la psique inconsciente, sueño, imaginación y subjetividad (C. G. Jung), de manera a explorar sus interrelaciones con el consumo (Baudrillard, Bauman) y sus imaginarios semióticos e ideología, enfocando los conceptos de sueños de consumo y mundos de sueño del consumo. El objetivo principal fue explorar de qué maneras los sueños representan la colonización de la subjetividad por el imaginario de consumo. El método consiste en un estudio de múltiples casos en el cual cada sueño fue tomado como un caso e interpretado a través de la hermenéutica junguiana. Los hallazgos subrayan que los sueños pueden revelar una crítica sociocultural profunda; en ellos el imaginario de consumo aparece como una ideología de masa totalizante que engendra procesos de colonización de imaginarios simbólicos y del sujeto y su psique inconsciente. En las conclusiones se enfatiza dicha colonización como una mutación antropológica - la progresiva mercantilización y deshumanización del sujeto.
\end{abstract}

Xavier, Marlon (2013). Consumption dreams: how night dreams reveal the colonization of subjectivity by the imaginary of consumerism. Athenea Digital, 13(2), 289-295. Disponible en http://psicologiasocial.uab.es/athenea/index.php/atheneaDigital/article/view/Xavier

\footnotetext{
1 Tesis doctoral dirigida por Josep M. Blanch. Departamento de Psicología Social, Universitat Autònoma de Barcelona.
} 
We all have the feeling that we are being colonisedbut we don't exactly know who by; the enemy is not easily identifiable.

Marc Augé

And it is the workings and processes of an unconscious social logic that must be retrieved beneath the consecrated ideology of consumption.

Jean Baudrillard ${ }^{2}$

This doctoral work pertains to the field of studies on subjectivity within the context of postmodern consumer society, or consumerism. It assumes that consumerism defines not only contemporary capitalism but our global ethos. Indeed, consumption has arguably become the main definer of our culture, the chief basis of the social order (Baudrillard, 1968/1996; Poster, 2001): we are living in the age of consumerism (Baudrillard, 1970/1998). As a globalized socioeconomic system, consumer capitalism seeks to produce and shape its subjects according to its logic and needs; it thus turns into the main social mode of production of psychological life - of colonization and engineering of subjectivity. Presently, the result is that what ultimately defines the subject is being a consumer (Baudrillard, 1970/1998; Bauman, 2007; Dufour, 2008; Gottdiener, 1996) and, furthermore, his/her transformation into a commodity. According to Zygmunt Bauman (2007, p. 12), that has in fact become "The most prominent feature of the society of consumers (...) the transformation of consumers into commodities" - the mass production of commodity-subjects, a relentless colonization of being.

Proposing a focus on the concept of unconscious ${ }^{3}$ for the research of such themes, this dissertation studies the social imaginary of consumerism, and the psychological subject it produces, through the dream - as both a leitmotif or thematic lens, and the empirical object of research. It thus seeks to unveil and investigate the dialectics between dreaming and mass culture involved in the postmodern fabrication of subjectivity. This proposal is founded upon the idea that, by expressing the discourse of the unconscious, night dreams can reveal a critical view of culture, subjectivity, and their dialectical relationships. Therefore, it is via the dream that this work tries to illuminate the unconscious social logic, the "subterranean stream" (Arendt, 1958, p. ix) beneath consumerism's production of subjects.

So, as the polysemic leitmotif of this work, "dream" appears in three main senses:

(a) as night dream - the symbolic, natural product of the unconscious psyche that reveals its discourse on the dreamer's subjectivity and on (consumer) culture;

(b) as consumption dreams - defined as the desires, fantasies, and daydreams about commodities and consumption, they correspond to the irrational fetish or ideology, the social significations fabricated and circulated as a social imaginary through the logic of advertising, which engineer collective desire and imagination and underpin the functioning of the whole system of consumption. This concept condenses the idea that contemporary consumerism is largely sustained by the immaterial, the fictional, the imaginary: it depends fundamentally on the marketing and consumption of dreams (Ewen, 1990);

(c) as dream-worlds of consumption - as in the concept formulated by Walter Benjamin (Benjamin, 1999; Buck-Morss, 1989, 2000; Williams, 1991), here they are embodied by McDonald's, Disneyland, shopping malls, and department stores, and appear as the scenarios ("dreamscapes") or main themes of the night

\footnotetext{
${ }^{2}$ Augé, 1999, p. 6; Baudrillard, 1973/1981, p. 63.

${ }^{3}$ Based on a (Jungian) theory on the unconscious psyche that is paradigmatically different from the psychoanalytic and schizoanalytic approaches.
} 
dreams researched empirically; they signify typical forms of cultural colonization by the consumption ethos (forms studied in sociology under the theories of McDonaldization and Disneyization) and symbolize the imaginary of consumerism globally.

In relation to consumption and its social imaginary, the theoretical perspective advanced in this work, based on Max Weber's notion of ideal types, assumes that consumerism actualizes the totalizing imperative of capitalism ${ }^{4}$ pointed out by Karl Marx (1858/1978), Georg Lukács (1923/1971), and Cornelius Castoriadis (1997): its characteristic proclivity to colonizing and "subordinating all elements of society to itself" (Marx, 1858/1978, p. 278). Such perspective was summarized through the concept of total capitalism (Dufour, 2008; Leys, 2007), referring to consumerism's telos of total commodification everything must become a commodity, including, and most importantly, the subject.

\section{Dissertation overview}

The structure of this dissertation reflects the hypothesis that the Imaginary of Consumerism represents a historical mutation and a colonizing force (in relation to other imaginaries, subjectivity, and dreams); it engenders what Serge Gruzinski (1988) called a "colonization of imaginaries", thus producing "the new regime of the imaginary which nowadays touches social life, contaminating and penetrating it [i.e., colonizing it] to the point where we mistrust it, its reality, meaning and the categories (identity, otherness) which shape and define it" (Augé, 1999, pp. 2-3). The dissertation structure therefore conflates and compares two distinct forms of social imaginaries and two concepts of dream. The argument is: if there is colonization - or a mutation - then we need two distinct historical and cultural perspectives, so as to distinguish or point at differences, at what is/has been colonized. Or, in more simple terms: how it is "without", or before, colonization; and after, under colonization.

Thus the Part I of this study, presenting its theoretical framework, consists of two blocks. The first block, comprising the first two chapters, offers a general theoretical basis for the whole dissertation, which is grounded on C. G. Jung's analytical psychology in an interdisciplinary dialog with different sociological traditions (Émile Durkheim, Lucien Lévy-Bruhl, Gilbert Durand, Marc Augé). It explores the idea of social imaginaries (Durand, 1963, 1994, 1996, 2004; Taylor, 2004) as being historically and culturally symbolic, originally founded upon the unconscious psyche, and naturally connected to the world of dreams. The discussion aims at situating the reader in relation to analytical psychology and its concepts, yet it also draws upon anthropological, sociological, and ethnological arguments and literature.

Its Chapter 1 explores the concept of symbolic imaginaries, a psychology of the unconscious and its symbolic and imaginative function, and their relations with subjectivity. Underlying such discussion is the theory on archetypes, which grounds a unique theorization on the symbol, its difference with the concept of sign, and its import as the fundament of what is human (Ernst Cassirer's idea of homo symbolicum). The chapter concludes by relating such topics with the concepts of représentations collectives (Durkheim, Lévy-Bruhl) and participation mystique (Lévy-Bruhl).

Chapter 2 provides a general theoretical discussion on the subject of dreams and their relations to the other research subjects. Dreams as important origins of symbolic imaginaries and cultures, and their specific significance, roles, and functions in the latter, are presented. Next the main theoretical fundaments regarding the concept of dream are discussed. Dream is conceptualized as a natural product

\footnotetext{
${ }^{4}$ The totalizing or even totalitarian aspects of capitalism have been pointed up by many contemporary scholars (e.g., Clarke, 2005; Fairclough \& Graham, 2002; Gare, 2008; Graham, 2006; Jha, 2006; Lacher, 2005; Lebowitz, 2003; Liodakis, 2010; Radice, 2005).
} 
of the unconscious and its symbolic function. Dynamics and functioning of the unconscious are explained through the dream as its embodiment. Possible relations between dream and subjectivity - the ways dreams can express or reveal subjectivity and social reality - depend on interpretative and hermeneutic outlooks, which are presented. It is the methodological proposition of applying simultaneously the interpretations on the subjective level and on the objective level (Jung, 1953) to the empirical night dream that situates the dream as object of study of the dialectical relationship between individual and culture, and reflects the idea of psychological dialogism put forward by cultural psychology (Valsiner, 1989, 2002).

The second block consists of Chapters 3 to 5 , and provides theoretical reflections on the concepts of Imaginary of consumption (ImCon) $)^{5}$ and consumption dreams, and their relations with subjectivity and its colonization. While drawing from a broad array of authors from distinct fields of academia, its main theoretical reference is Jean Baudrillard's work on consumer society and consumption. This block is aimed at presenting these authors' main contributions on such themes, but seen from and adapted to the viewpoint of the concept of social imaginary, and in dialog with the psychological perspective outlined in the first block.

Chapter 3 focuses on the discussion of the ImCon as a semiotic imaginary, its logic and characteristics, and its difference in relation to symbolic imaginaries; it is defined as a regime of signification composed of signs as social signifiers, which, like symbolic imaginaries, is also based on imagery and the irrational. The social logic of consumption (founded on the consumption of social signification through commoditysigns) and of commodification (as the production of sign-values) and a theory on the commodity-sign (as unit of analysis and elemental form of consumerism) as the main concepts for the understanding of consumerism are presented. Consumerism and its social imaginary are analyzed through the idea of dream, focusing on the concept of consumption dreams: as fundamental constituents of the ImCon, they are discussed as the imaginary social representations that, being mass-produced following the logic and practices of advertising, determine and colonize desires and irrational factors, and signify and institute the social subject as a consumer. Finally, the chapter discusses how the ImCon and its dreams define and colonize subjectivity, and the possible effects of such processes.

Chapter 4 discusses the idea that the ImCon may function as a simulacrum of symbolic-religious imaginary - a myth or desacralized religion based on a transcendental, totalizing ideology. Following the logics of total consumerism-capitalism, its colonization and fabrication of signification, imagination, fantasy, and dream imply the fabrication of an ideological hyperreality, which is discussed through Walter Benjamin's concept of dream-world of consumption. The concepts of fetish, phantasmagoria, and collective dream are then introduced to discuss the ImCon's mythico-ideological character and some of its effects. The chapter concludes by exploring the possibility that, by simulating a symbolic imaginary, the ImCon colonizes the unconscious psyche and, through archaic identity (participation mystique) and mimesis, institutes its subject as a consumer-commodity, or commodified self (Davis, 2003).

Finally, Chapter 5 explores the dreamscapes (the scenarios of the night dreams interpreted in this research: McDonald's, Disneyland, shopping malls) as dream-worlds of consumption, discussing how they symbolize particular aspects of the ImCon and its typical forms of colonization of culture and subjectivity, in a dialog with the sociological theories of McDonaldization (Bryman, 2004b; Ritzer, 1993, 1998, 2000, 2002) and Disneyization (Bryman, 1999, 2003, 2004a; Cypher \& Riggs, 2001; Wasko, 2001).

\footnotetext{
${ }_{5}$ The acronym ImCon was employed so as to give it an Orwellian flair. It can be read as social Imaginary of Consumption, and of Consumerism; as both expressions are rare in the literature in English, ImCon seemed a good rendition of the adequate and common expression in French, l'imaginaire de (la) consommation (as appearing in, e.g., Zaki Laïdi, 2004; Jean-Michel Normand, 2004; and Pascale Weil, 1993).
} 
Part II is dedicated to the empirical section of this work and comprises Chapters 6 to 10 . Chapter 6 , on Method, describes the qualitative methodological design employed in this research, which consists in a multiple-case study in which each night dream was a case. From a corpus of more than 1400 night dreams collected from various sources (but mainly volunteered on the internet, as dream series, to nonclinical settings), 16 dreams were selected according to their themes, relevance, and informationrichness (Patton, 1990). Each dream was interpreted through Jungian symbolic hermeneutics, which is discussed. The process of interpretation and theory-generation followed a hypothetico-deductive approach.

Chapters 7 to 10 are dedicated to presenting the findings of this study through the interpretation and discussion of its empirical material, the night dreams, focusing on which subjective factors or domains appear colonized in them, how consumer culture seems to be criticized by them, and the general implications or effects of colonization that they seem to show in relation to both subjects and culture. Among the main findings, this work demonstrates that night dreams can reveal an objective and deep critique of sociocultural reality. Such critique was centered upon the idea that the imaginary of consumption engenders a massive colonization of symbolic imaginaries, in a process of absorption and substitution, replacing their symbols with fabricated signs and simulacra. Its semiotic imagery and narratives appear as a totalizing ideology - the regime of consumerism - that functions as archaic représentations collectives and simulates a religious, mythic imaginary. Dreams represented such imaginary as producing manifold forms of colonization of subjectivity, which may be subsumed under a general form: the commodification of different psychological factors that are definers of subjective identity, but especially of irrational factors such as desires, emotions, imagination, and instincts. This process of colonization was understood through the concept of participation mystique, as an archaic unconscious identity with the imaginary in which the subject replicates the latter, becoming identical to it to some extent. Some dreams unveiled such archaic identity as being the basis for a colonization of the subjects' symbolic function and their unconscious psyche.

Finally, the dissertation closes with the Conclusions, which present a condensation and articulation of its major findings in relation to the main research aims proposed. Here it seems adequate to stress what is perhaps the most important image and idea unveiled by the dreams: they disclosed the fully totalitarian character of the ImCon and the regime of consumerism, functioning as a totalizing mass ideology striving to attain complete monopoly of social signification and imagery, in the Lebenswelt but also in the very depths of the subjects' unconscious psyches - thus actualizing its telos of becoming total, of colonizing, producing, and controlling totally both world and subject. Dreams also illustrated and disclosed many of the possible implications of such sociocultural and subjective processes; the most important implication seemed to be that the cultural mutation of imaginaries - the semiotic imaginary of consumerism colonizing and erasing the original symbolic imaginaries, and passing over to an order of simulacra begets a parallel anthropological mutation, which was symbolized as a progressive commodification and dehumanization of being: from homo symbolicum to the subject manufactured by the regime of consumerism - the homo simulacrum.

\section{References}

Arendt, Hannah (1958). The origins of totalitarianism. New York: Meridian Books.

Augé, Marc (1999). The war of dreams: exercises in ethno-fiction (L. Heron, Trad.). London: Pluto Press. Baudrillard, Jean (1968/1996). The system of objects (J. Benedict, Trad.). London: Verso. 
Baudrillard, Jean (1973/1981). For a critique of the political economy of the sign. St. Louis, MO: Telos Press.

Baudrillard, Jean (1970/1998). The consumer society: Myths and structures. London: Sage.

Bauman, Zygmunt (2007). Consuming life. Cambridge: Polity Press.

Benjamin, Walter (1999). The Arcades Project (H. Eiland \& K. McLaughlin, Trad.). Cambridge, MA: The Belknap Press of Harvard University Press.

Bryman, Alan (1999). The Disneyization of society. Sociological Review, 47, 25-47.

Bryman, Alan (2003). McDonald's as a Disneyized institution: Global implications. American Behavioral Scientist, 47(2), 154-167.

Bryman, Alan (2004a). Disneyization. Encyclopedia of Social Theory. SAGE Publications. Extraido el 6 de abril de 2010, de http://www.sage-ereference.com/socialtheory/Article n81.html

Bryman, Alan (2004b). McDonaldization. Encyclopedia of Social Theory. SAGE Publications. Extraido el 6 de abril de 2010, de http://www.sage-ereference.com/socialtheory/Article n187.html

Buck-Morss, Susan (1989). The dialectics of seeing: Walter Benjamin and the Arcades Project. Cambridge, MA: MIT.

Buck-Morss, Susan (2000). Dreamworld and catastrophe: The passing of mass utopia in East and West. Cambridge, MA: MIT.

Castoriadis, Cornelius (1997). The "rationality" of capitalism. En The anonymous Translator/Editor" (Coomp.), Figures of the unthinkable (pp. 81-122). Extraido el 10 de mayo de 2010, de http://www.costis.org/x/castoriadis/Castoriadis-Figures_of the_Thinkable.pdf

Clarke, Simon (2005). The neoliberal theory of society. En Alfredo Saad-Filho \& Deborah Johnston (Eds.), Neoliberalism: A critical reader (pp. 50-59). London: Pluto Press.

Cypher, Jennifer \& Riggs, Eric (2001). Colonizing the imagination: Disney's Wilderness Lodge. Critical studies, 21, 403-423.

Davis, Joseph E. (2003). The commodification of self. Hedgehog Review, 5(2), 41-49.

Dufour, Dany-Robert (2008). The art of shrinking heads: The new servitude of the liberated in the era of Total Capitalism. Cambridge and Oxford: Polity.

Durand, Gilbert (1963). Les structures anthropologiques de l'imaginaire. Paris: Dunod.

Durand, Gilbert (1994). L'imaginaire: Essai sur les sciences et la philosophie de l'image. Paris: Hatier.

Durand, Gilbert (1996). Introduction à la mythodologie. Mythes et sociétés. Paris: Albin Michel.

Durand, Gilbert (2004). Las estructuras antropologicas del imaginario: Introducción a la arquetipología general. Mexico: FSE.

Ewen, Stuart (1990). Marketing dreams: The political elements of style. En Alan Tomlinson (Ed.), Consumption, identity and style: marketing, meanings, and the packaging of pleasure (pp. 2939). London: Routledge.

Fairclough, Norman \& Graham, Phil (2002). Marx as critical discourse analyst: the genesis of a critical method and its relevance to the critique of global capital. Estudios de Sociolingüística, 3(1), 185-229.

Gare, Arran (2008). Marxism and the problem of creating an environmentally sustainable civilization in China. Capitalism, Nature, Socialism, 19(1), 5-26.

Gottdiener, Mark (1996). The theming of America: Dreams, visions, and commercial spaces. Boulder, CO: Westview Press.

Graham, Phil (2006). 'Capitalism' as false consciousness. Studies in Language \& Capitalism, 1, 57-76. Gruzinski, Serge (1988). La colonization de l'imaginaire. Paris: Gallimard.

Jha, Prem S. (2006). The twilight of the nation state: Globalisation, chaos and war. London: Pluto Press. Jung, Carl Gustav (1953). Two essays on analytical psychology (R. F. C. Hull, Trad.). En The Collected Works of C. G. Jung (Vol. 7). London: Routledge and Kegan Paul. 
Lacher, Hannes (2005). International transformation and the persistence of territoriality: Toward a new political geography of capitalism. Review of International Political Economy, 12(1), $26-52$.

Laïdi, Zaki (2004). La mondialisation est aussi un imaginaire. Ceras - revue Projet, 287, Extraido el 31 de enero de 2011, de http://www.ceras-projet.com/index.php?id=1134

Lebowitz, Michael A. (2003). Beyond 'Capital': Marx's political economy of the working class (2a ed.). Basingstoke (UK): Palgrave MacMillan.

Leys, Colin (2007). Total capitalism: Market politics, market state. London: Merlin Press.

Liodakis, George (2010). Totalitarian capitalism and beyond. Surrey (UK): Ashgate.

Lukács, Georg (1923/1971). History and class consciousness (R. Livingstone, Trad.). London: Merlin Press.

Marx, Karl (1858/1978). Grundrisse. En Robert C. Tucker (Ed.), The Marx-Engels reader (2a ed.) (pp. 222-293). New York: WW Norton.

Normand, Jean-Michel (2004). Les nouveaux imaginaires de la consommation: Chroniques du Monde (1999-2004). Paris: Presses Universitaires de France.

Patton, Michael Q. (1990). Qualitative research and evaluation methods. Newbury Park: Sage

Publications.

Poster, Mark (2001). Introduction. En Mark Poster (Ed.), Jean Baudrillard: Selected writings (2a ed.) (pp. 1-9). Cambridge: Polity.

Radice, Hugo (2005). Neoliberal globalization: Imperialism without empires? En Alfredo Saad-Filho \&

Deborah Johnston (Eds.), Neoliberalism: A critical reader (pp. 91-98). London: Pluto Press.

Ritzer, George (1993). The McDonaldization of society. Thousand Oaks, CA: Pine Forge.

Ritzer, George (1998). The McDonaldization thesis. London: Sage.

Ritzer, George (2000). The McDonaldization of society: New Century edition. Thousand Oaks, CA: Pine Forge.

Ritzer, George (2002). McDonaldization: The reader. London: Sage.

Taylor, Charles (2004). Modern social imaginaries. Durham and London: Duke University Press.

Valsiner, Jaan (1989). Human development and culture: The social nature of personality and its study.

Massachusetts: Lexington Books.

Valsiner, Jaan (2002). Forms of dialogical relations and semiotic autoregulation within the self. Theory and Psychology, 12(2), 251-265.

Wasko, Janet (2001). Understanding Disney: The manufacture of fantasy. Cambridge (UK): Polity.

Weil, Pascale (1993). A quoi revent les annees 90: Les nouveaux imaginaires - consommation et communication. Paris: Seuil.

Williams, Rosalind H. (1991). Dream worlds: mass consumption in late nineteenth-century France. Berkeley: University of California Press.

\begin{tabular}{l}
\hline Este texto está protegido por una licencia Creative Commons. \\
Usted es libre de copiar, distribuir y comunicar públicamente la obra bajo las siguientes condiciones: \\
Reconocimiento: Debe reconocer y citar al autor original. \\
No comercial. No puede utilizar esta obra para fines comerciales. \\
Sin obras derivadas. No se puede alterar, transformar, o generar una obra derivada a partir de esta obra. \\
Resumen de licencia - Texto completo de la licencia
\end{tabular}

